\title{
Review \\ EGFR Exon 20 Insertion Mutations in Sinonasal Squamous Cell Carcinoma
}

\author{
Laura Pacini ${ }^{1}\left(\mathbb{D}\right.$, Virginia N. Cabal ${ }^{2}$, Mario A. Hermsen ${ }^{2}$ and Paul H. Huang ${ }^{1, *(1)}$ \\ 1 Division of Molecular Pathology, The Institute of Cancer Research, Sutton SM2 5NG, UK; \\ laura.pacini@icr.ac.uk \\ 2 Department Head and Neck Cancer, Instituto de Investigación Sanitaria del Principado de Asturias (ISPA), \\ Centro de Investigación Biomédica en Red (CIBER-ONC), 33011 Oviedo, Spain; \\ vncabal@ispasturias.es (V.N.C.); mhermsen@hca.es (M.A.H.) \\ * Correspondence: paul.huang@icr.ac.uk
}

Citation: Pacini, L.; Cabal, V.N.; Hermsen, M.A.; Huang, P.H. EGFR Exon 20 Insertion Mutations in Sinonasal Squamous Cell Carcinoma. Cancers 2022, 14, 394. https:// doi.org/10.3390/cancers14020394

Academic Editor: Nora Katabi

Received: 26 November 2021

Accepted: 7 January 2022

Published: 13 January 2022

Publisher's Note: MDPI stays neutral with regard to jurisdictional claims in published maps and institutional affiliations.

Copyright: (c) 2022 by the authors. Licensee MDPI, Basel, Switzerland. This article is an open access article distributed under the terms and conditions of the Creative Commons Attribution (CC BY) license (https:// creativecommons.org/licenses/by/ $4.0 /)$.
Simple Summary: The majority of patients with sinonasal squamous cell carcinoma (SNSCC) associated with inverted sinonasal papilloma carry an exon 20 insertion activating mutation in the epidermal growth factor receptor (EGFR). The aim of this review is to document the various features of EGFR mutations in SNSCC and other cancers, and to assess what we can learn from the study of these mutations in lung cancer, with a special focus on new therapeutic opportunities for SNSCC patients carrying EGFR exon 20 insertions mutations.

\begin{abstract}
Recurrent epidermal growth factor receptor (EGFR)-activating mutations have been identified in a rare form of head and neck cancer known as sinonasal squamous cell carcinoma (SNSCC), a malignant disease with a 5-year mortality rate of $\sim 40 \%$. Interestingly, the majority of EGFR mutations identified in patients with primary SNSCC are exon 20 insertions (Ex20ins), which is in contrast to non-small-cell lung cancer (NSCLC), where the EGFR exon 19 deletion and L858R mutations predominate. These studies demonstrate that EGFR Ex20ins mutations are not exclusive to lung cancer as previously believed, but are also involved in driving SNSCC pathogenesis. Here we review the landscape of EGFR mutations in SNSCC, with a particular focus on SNSCC associated with inverted sinonasal papilloma (ISP), a benign epithelial neoplasm. Taking lessons from NSCLC, we also discuss potential new treatment options for ISP-associated SNSCC harbouring EGFR Ex20ins in the context of targeted therapies, drug resistance and precision cancer medicine. Moving forward, further basic and translational work is needed to delineate the biology of EGFR Ex20ins in SNSCC in order to develop more effective treatments for patients with this rare disease.
\end{abstract}

Keywords: EGFR; exon 20 insertions; sinonasal squamous carcinomas; tyrosine kinase inhibitors; drug resistance

\section{Introduction}

Sinonasal squamous cell carcinoma (SNSCC) is a rare malignancy accounting for 3-5\% of head and neck cancer cases and $75 \%$ of all sinonasal tumours [1-3]. SNSCCs arise from mucosal sites throughout the paranasal sinuses, with the most common originating sites being the nasal cavity and the maxillary sinus [4]. Surgical resection is the treatment of choice in early-stage SNSCC, however, advanced stage tumours can be difficult to resect because of the complexity of the sinonasal anatomy and the proximity to the skull base and orbital cavity [5]. Although surgery with concomitant chemotherapy or radiotherapy have improved the management of this disease, prognosis of patients with SNSCC remain poor, with a 5-year survival rate of approximately $40 \%[2,3,6,7]$. This is in part due to the high rate of local recurrence that has been shown to occur within 2 years of follow-up in $31-56 \%$ of cases $[5,8-10]$. Lymph node metastases are relatively infrequent and are found in approximately $10-20 \%$ of cases [5,9]. Poor survival is also dependent on the stage 
of presentation due to often unspecific symptoms such as rhinorrhoea, the difficulty in accessing the tumour due to proximity to vital structures and aetiologic variability.

The aetiology of SNSCC is not fully understood, although several studies have suggested tobacco use, occupational exposures and human papillomavirus (HPV) infection may be risk factors [11-14]. Another important aetiologic risk for SNSCC is the malignant transformation from inverted sinonasal papilloma (ISP), a locally aggressive benign epithelial neoplasm that arises from the ectodermally derived pseudostratified ciliated (or Schneiderian) epithelium that lines the nasal cavity and sinonasal tract [1,4]. However, SNSCC can also arise as primary malignant tumours without clinical or pathological evidence of an associated papilloma (de novo SNSCC). ISP is the most common sinonasal papilloma subtype based on histological classification (64\%), followed by exophytic (ESP, $32 \%$ ) and oncocytic (OSP, 6\%) [15]. These subtypes present fundamental diversities not only based on their histology but also in relationship with their location and viral aetiology. For instance, ESP are tumours driven by low-risk HPV that usually arise in the nasal septum and are only rarely associated with SNSCC. While OSP and ISP share a similar location (the lateral nasal wall and sinuses) and show a similar frequency of malignant transformation in 5-25\% and can be associated with synchronous or metachronous SNSCC [12,16-18]. Recently, activating mutations in the epidermal growth factor receptor (EGFR) and the Kirsten rat sarcoma 2 viral oncogene homolog (KRAS) genes have been identified in about $90 \%$ of ISP and ISP-associated SNSCC and in 100\% of OSP, respectively, but not in ESP or de novo SNSCC [19-21]. For the purpose of this review, we will focus on recurrent activating EGFR mutations in ISP and ISP-associated SNSCC.

This review was performed by a systematic search of PubMed using keywords relevant to the topic. The most relevant articles and systematic reviews of the two fields discussed (sinonasal squamous cell carcinoma and EGFR exon 20 insertions) were then chosen and reported in the review. The reporting of this review was guided by the standards of the Preferred Reporting Items for Systematic Review and Meta-Analysis (PRISMA) Statement.

\section{Overview of the Epidermal Growth Factor Receptor (EGFR)}

EGFR is a member of the ErbB family of receptor tyrosine kinases (RTK), which also includes HER2 (ErbB2), HER3 (ErbB3) and HER4 (ErbB4). EGFR is a single-chain transmembrane glycoprotein activated by the binding of various ligands including epidermal growth factor (EGF) and transforming growth factor $\alpha$ (TGF $\alpha$ ) [22]. Ligand binding promotes receptor dimerization which drives the autophosphorylation and activation of the kinase domain inducing the phosphorylation of tyrosine residues on the C-terminal tail of EGFR, which act as docking sites for downstream signalling proteins [23]. A schematic representation of EGFR structure and domains is shown in Figure 1. Some of the main signalling pathways triggered by EGFR activation include the rat sarcoma virus (RAS) and mitogen-activated protein kinase (MAPK), phosphatidylinosinol 3-kinase/protein kinase $\mathrm{B}$ (PI3K/AKT), phospholipase C-gamma (PLC) and signal transduction and activation of transcription (STAT) pathways. The activation of these pathways regulates cell survival, proliferation and differentiation [24,25]. EGFR plays a crucial role in the physiological regulation of epithelial tissue development and homeostasis $[26,27]$. In the pathological setting, it is considered an important driver of tumorigenesis, widely studied mostly in lung and breast cancer and glioblastoma (GBM) [28,29]. 
A

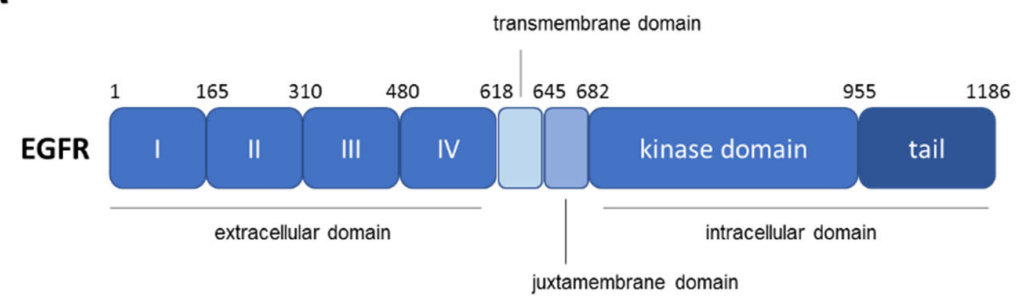

B

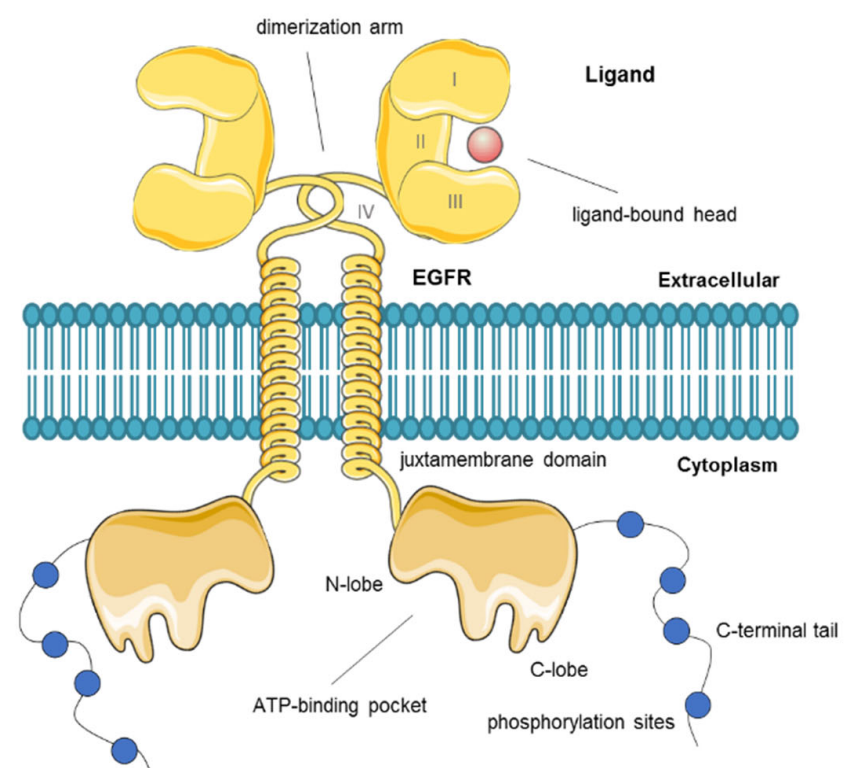

Figure 1. Schematic representation of human EGFR structure and domains. (A) Domain boundaries in EGFR with amino acid positions. (B) Depiction of the structure of the EGFR dimer in the cell membrane with indication of its various domains and functions.

\section{EGFR Mutations in Cancer}

Given that EGFR activates signalling networks associated with promoting cell survival, growth, invasion and proliferation, it is unsurprising that aberrations that result in hyperactivation of EGFR are common in many cancers. This has led to the extensive investigation of EGFR as a therapeutic target. The mechanisms by which EGFR becomes oncogenic are numerous, mainly resulting from amplification and point mutations at the genomic locus giving rise to constitutively active variants. Ligand overproduction, transcriptional upregulation, defective downregulation of EGFR and cross-talk with heterologous receptor systems have also been described [30]. EGFR mutations, amplifications or in-frame deletions can occur in regions corresponding to the extracellular or intracellular portions of the protein and are quite specific to different cancer types.

For instance, in GBM, EGFR is among the most commonly altered genes and mutations occur mainly in the extracellular domain $[28,30,31]$. A large in-frame deletion in the extracellular domain of EGFR spanning exons 2-7 which encode domains I and II, known as EGFRvIII, is the most common and well-studied GBM-associated EGFR mutant [32], although less common point mutations in the extracellular domain have also been identified in GBM [31,33,34]. Preclinical studies have shown a certain degree of sensitivity against EGFR tyrosine kinase inhibitor (TKI) therapy, especially the ATP-irreversible second- and third-generation inhibitors, neratinib and osimertinib, respectively [35,36]. Clinical trials are currently ongoing to evaluate the activity of these inhibitors on GBM patients carrying EGFRvIII mutations [35,37].

Traditionally, non-small-cell lung cancer (NSCLC) can be classified based on histological differences into adenocarcinoma $(\sim 50 \%)$, squamous cell carcinoma $(\sim 20 \%)$ and large cell 
carcinoma $(\sim 3 \%)$. The majority of lung adenocarcinomas and squamous cell carcinomas have known oncogenic driver mutations. EGFR mutations represent the second most common oncogenic driver event in lung cancer and accounts for $\sim 15-20 \%$ of lung adenocarcinoma cases, while EGFR mutations are rare in other NSCLC subtypes [38,39]. These mutations are generally restricted to four exons (exons 18-21) in the intracellular kinase domain. The two most common mutations, in-frame deletions in exon 19 (Ex19del) affecting the amino acid motif LREA (E746-750del) and substitution of arginine for leucine at position 858 (L858R) in exon 21, are referred to as "classical" EGFR mutations and together account for approximately $85 \%$ of EGFR mutations in patients with NSCLC [40]. These mutations can result in the constitutive activation of signal transduction pathways, leading to cell proliferation and survival regardless of the presence of extracellular ligands. NSCLC patients with these activating EGFR mutations are associated with high response rates to EGFR TKIs, including the competitive, ATP-reversible first-generation inhibitors (gefitinib and erlotinib) and the irreversible second- and third-generation inhibitors (afatinib and osimertinib, respectively) [41].

Exon 20 insertions (Ex20ins) are the third most common EGFR mutations to occur in NSCLC after L858R and Ex19del [42,43]. Ex20ins comprise a heterogeneous range of in-frame insertions or duplications that account for 4-10\% EGFR mutations in NSCLC [42,44-47]. Similar to Ex19del, there are differences in the exact size and position of the insertion, which ranges from 1-7 amino acids (762-774 amino acid position) most commonly in the loop that follows the $\alpha$ C-helix [46,47]. Recent 3D modelling studies have demonstrated that these mutations lead to a reorganization of critical amino acid residues, which in turn stabilizes ATP binding leading to increased tyrosine kinase activity in the absence of ligand binding [46]. The majority of NSCLC patients harbouring EGFR Ex20ins are resistant to clinically approved first- and second-generation EGFR TKIs with low response rates of between 0 and $27 \%$ and a median progression-free survival (PFS) of $<3$ months [48-51]. Three-dimensional modelling suggests that significant structural alterations caused by the Ex20ins result in a restricted size of the ATP binding pocket, limiting the binding of first-generation EGFR TKIs [52]. In recent years, a new generation of compounds capable of selectively targeting EGFR Ex20ins have been evaluated in a number of clinical trials involving NSCLC patients and two new targeted therapies have recently been approved by the US Food and Drug Administration (FDA) for the treatment of this previously undruggable molecular subtype of NSCLC.

\section{EGFR Mutations in SNSCC}

While ISPs are considered benign, these tumours have a high rate of local recurrence and can be highly invasive leading to facial deformities and even death in some cases [53]. Moreover, approximately 10-25\% cases of ISP are associated with synchronous or metachronous SNSCC [53]. However, the pathogenesis and molecular mechanisms driving oncogenicity in these tumours were unknown until recently. In 2015, a study from Udager et al. investigated the presence of pathogenic somatic mutations by performing next-generation sequencing using a targeted mutation hotspot panel (Ion AmpliSeq Cancer Hotspot Panel) on formalin fixed, paraffin-embedded (FFPE) archival tissues comprising nine ISP, four ISP-associated SNSCC and three non-ISP-associated SNSCC [19]. In this study, the authors identified a high prevalence of EGFR mutations in the ISP (7/9) and ISP-associated SNSCC (3/4) cases, but no EGFR mutations were observed in the non-ISPassociated SNSCC (0/3) samples. Importantly, this was the first ever study that specifically evaluated EGFR mutations-which are rare in head and neck cancer overall-in SNSCC and ISP [54]. In the same study, EGFR Exon 18 to 21 was subjected to further analysis by Sanger sequencing in a cohort of FFPE tissue samples from 50 ISP patients and from 22 patients with ISP-associated SNSCC [19]. A total of 19 different EGFR mutations were identified in $88 \%$ (44 of 50) ISP and 77\% (17 of 22) ISP-associated SNSCC tumours. Only one mutation was identified in each tumour and all mutations were confirmed to be somatic by Sanger sequencing of DNA from both tumour and matched normal tissue. Interestingly, the 
majority of identified EGFR mutations were Ex20ins (96\% of ISP and 88\% of ISP-associated SNSCC), involving residues located between A767 and V774. The most frequent EGFR Ex20ins found in the ISP tissues were S768_D770 duplication (S768_D770dup) (25\%) and N771_H773dup (18\%). Notably, the N771_H773dup was also the most frequent mutation in the ISP-associated SNSCC (29\%) followed by S768_D770dupSVD (24\%). The other nonEx20ins mutations found were an EGFR deletion-insertion in exon 19 (E746_S752delinsT) in 1/44 ISP case and 2/17 ISP-associated SNSCC and a nucleotide substitution in exon 19 (L747P) in 1/44 ISP. It is interesting to note that the frequency of EGFR mutations in these SNSCC tumours is distinct from NSCLC, where Ex20ins are rare, while the Ex19del and L858R mutations predominate. A schematic representation of EGFR mutations in NSCLC and ISP-associated SNSCC is shown in Figure 2.

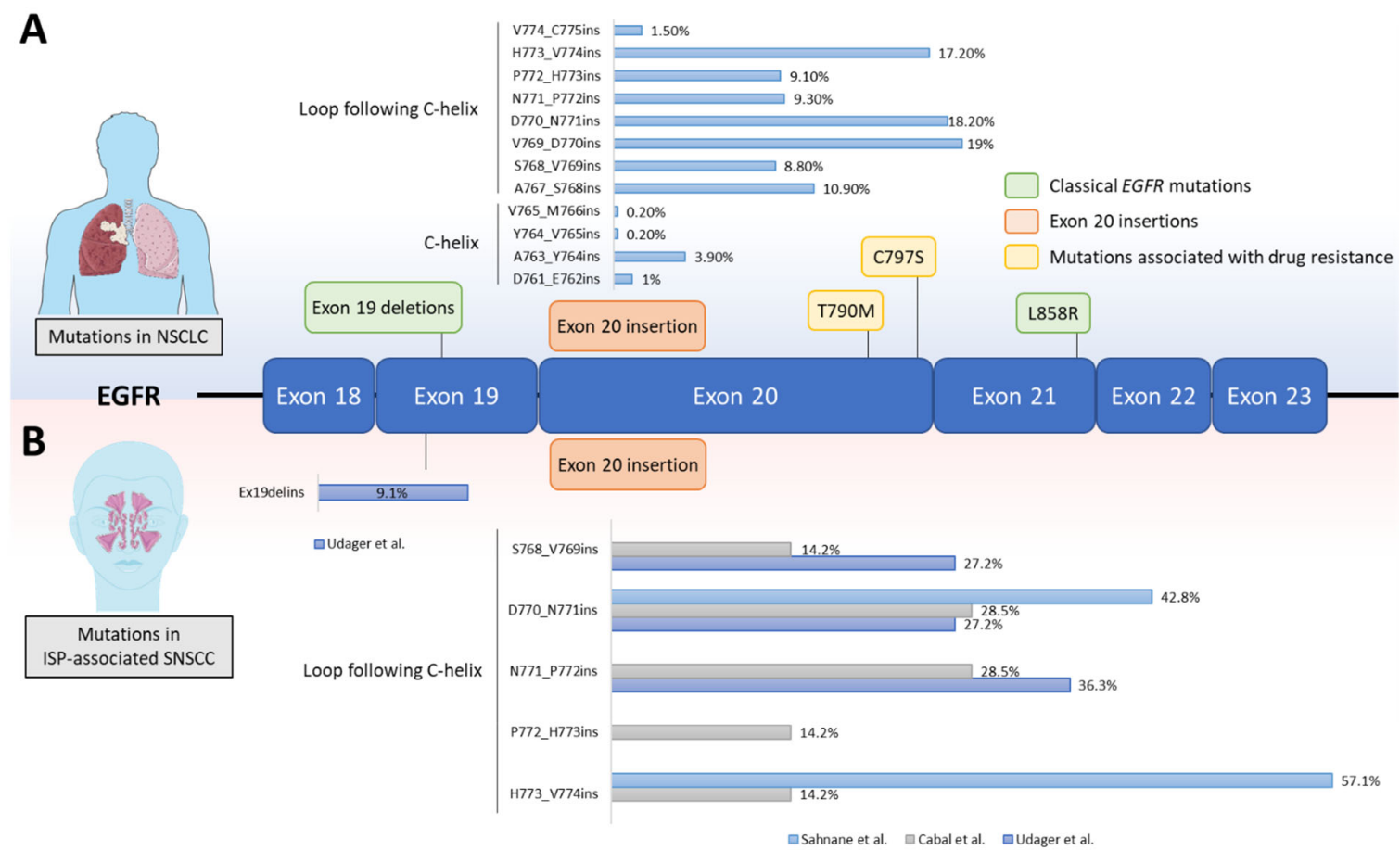

Figure 2. EGFR mutations in NSCLC and ISP-associated SNSCC. A schematic representation of the EGFR kinase domain is shown. (A) All EGFR mutations in NSCLC are clustered across exon 18-22, which encode the tyrosine kinase domain. The most common EGFR mutations in NSCLC are referred to as 'classical' EGFR mutations (green) and account for approximately 85\% of all EGFR mutations in NSCLC patients. The point mutations T790M and C797S (yellow) are associated with resistance to first- and third-generation EGFR TKIs, respectively. The prevalence of exon 20 insertions (orange) in NSCLC that occur at different amino acid positions are shown in the bar chart. Mutation frequency distribution was calculated using COSMIC v86 (http:/ / cancer.sanger.ac.uk, 10 November 2021) after filtering for NSCLC adenocarcinoma patients with exon 20 insertions $(n=383)$ [55]. (B) Frequency of exon 20 insertions and exon 19 deletion-insertion in ISP-associated SNSCC across 3 different studies are shown in the bar charts $[19,20,56]$.

Furthermore, identical EGFR genotypes were observed in 12 patients with an ISP and an associated SNSCC when the DNA from each tumour was separately extracted, providing the first molecular evidence to support the role of ISP as a precursor for SNSCC [19]. These results were confirmed in later studies conducted by different groups [20,56-60]. In one study, genotyping analysis for hot-spot mutations in 10 genes (KRAS, EGFR, BRAF, phosphatidynositol-4, 5-bisphosphate 3-kinase catalytic subunit alpha (PIK3CA), NRAS, anaplastic lymphoma receptor tyrosine kinase $(A L K), E R B B 2$, discoidin domain receptor tyrosine kinase 2 (DDR2), RET and MAPK21) was performed in a cohort of 65 FFPE specimens from 54 patients distributed as follows: 25 ISP (18 patients), 5 OSP, 24 ISP- 
associated SNSCC (19 patients) and 12 de novo SNSCC [20]. ISP showed EGFR mutations in 18/25 samples (72\%), while the remaining samples were wild type for all the genes. Among SNSCC samples, EGFR mutations were identified in 2/12 de novo SNSCC (17\%) and in 7/23 ISP-associated SNSCC (30\%). A total of seven different EGFR mutation types were identified, which were mainly Ex20ins involving the D770-V774 region [20]. Again, identical EGFR genotypes were observed in paired ISP and ISP-associated SNSCC from $6 / 7$ patients, confirming the existence of a clonal relationship between ISP and synchronous and metachronous SNSCC [20]. Moreover, Cabal et al. have also reported the presence of frequent EGFR Ex20ins in 7/18 (38\%) ISP and 6/12 (50\%) ISP-associated SNSCC but hardly any in de novo SNSCC (5\%, 1/19 samples), confirming previous studies [56]. All mutations exclusively concerned in-frame insertions affecting the region S768-V774 in exon 20, with 2 new mutations not previously described in the literature, N771delinsGS in one ISP specimen and P772_H773dupPDN in one de novo SNSCC sample [56]. A list of EGFR Ex20ins detected in SNSCC across the different studies is reported in Table 1.

Table 1. Prevalence and distribution of EGFR exon 20 insertions in ISP, ISP-associated SNSCC and de novo SNSCC.

\begin{tabular}{|c|c|c|c|c|}
\hline \multirow{2}{*}{ Mutation } & \multicolumn{3}{|c|}{ Frequency per Tumour Types } & \multirow{2}{*}{ Ref. } \\
\hline & ISP & ISP-Associated SNSCC & De Novo SNSCC & \\
\hline A767_V769dup & $2 \%$ & & & [19] \\
\hline S768_D770dup & $25 \%$ & $24 \%$ & & [19] \\
\hline V769_D770insGSV & $2 \%$ & & & [19] \\
\hline D770_P772dup & $5 \%$ & & & [19] \\
\hline D770_N771insGF & $2-17 \%$ & & & {$[19,58]$} \\
\hline D770_N771insSVD & $5-24 \%$ & $1-25 \%$ & & {$[20,56,58,60]$} \\
\hline D770_N771insGD & $2 \%$ & $6 \%$ & & [19] \\
\hline D770_N771insSVE & $2 \%$ & $6 \%$ & & [19] \\
\hline D770_N771insG & $2-6 \%$ & $2-7 \%$ & $1 \%$ & {$[19,20,56,58,60]$} \\
\hline D770_N771insGL & $2-9 \%$ & $6-7 \%$ & & {$[19,56,60]$} \\
\hline ]N771delinsGS & $2 \%$ & & & [56] \\
\hline N771delinsGF & $9 \%$ & & $1 \%$ & {$[19,60]$} \\
\hline N771delinsGY & $2 \%$ & $14 \%$ & & {$[19,56]$} \\
\hline ]N771delinsSG & $2 \%$ & & & {$[19]$} \\
\hline N771_P772insV & $2 \%$ & $6 \%$ & & {$[19,56]$} \\
\hline N771_H773dup & $18 \%$ & $29 \%$ & & [19] \\
\hline N771_P772insPDN & & $15 \%$ & $1 \%$ & {$[60]$} \\
\hline P772_H773dupPDN & & & $1 \%$ & [56] \\
\hline P772_H773insDNP & $9 \%$ & & & [58] \\
\hline H773_V774insGCRH & $2 \%$ & & & [19] \\
\hline H773dup & $11 \%$ & & & [19] \\
\hline H773_V774dup & $2 \%$ & & & [19] \\
\hline H773_V774insPH & $1 \%$ & & & [20] \\
\hline H773_V774insH & $3-4 \%$ & $1 \%$ & & {$[20,58]$} \\
\hline H773_V̄774insNPH & $3-9 \%$ & $2-45 \%$ & $1-2 \%$ & {$[20,56,58,60]$} \\
\hline
\end{tabular}

The frequency of EGFR mutations in ISP (39\%) in the study of Cabal et al. [56] was notably less than in previous studies that reported $72-91 \%$ of tumours harbouring mutations $[19,20,57,59,60]$. Among the ISP-associated SNSCCs, the reported frequency of EGFR Ex20ins also differs across different studies: 50\% in the Spanish cohort [56], 30\% in the Japanese cohort [57] and 72-77\% in the Italian and American studies, respectively [20,59]. A possible explanation for these differences could involve the geographic or ethnic factors, which has been observed in the enrichment of EGFR mutations in East Asian populations in lung cancer, but not enough evidence is available to support this hypothesis in head and neck cancer [57]. Finally, immunohistochemical expression of EGFR was also reported in a high proportion of ISP $(92 \%, 34 / 37)$, ISP-associated SNSCC $(60 \%, 6 / 10)$ and de novo SNSCC $(44 \%, 24 / 54)$, while the activated phosphorylated form pEGFR was observed in 
21/39 (54\%) ISP, 4/12 (33\%) ISP-associated SNSCC and 20/52 (38\%) of de novo SNSCC [56]. Interestingly, the activation of EGFR either through genetic mutations or protein phosphorylation appeared inversely correlated, with 3/12 (25\%) EGFR mutated cases versus 18/27 (67\%) EGFR wild-type cases also expressing pEGFR, suggesting that the activation of EGFR pathway may occur through different mechanisms in ISP-associated SNSCC and de novo SNSCC that have reported 50\% and 5\% Ex20ins mutations, respectively [56]. This may be explained by the fact that Ex20ins mutations lead to a protein conformation change that activates signalling independent of receptor dimerization and autophosphorylation [61].

In conclusion, all these findings in SNSCC open up the possibility for therapy with specific EGFR inhibitors. In the next section, we will review the current literature for previous generation and newly developed compounds that are able to target EGFR Ex20ins and discuss the advantages and disadvantages for the use of these targeted therapies in the treatment of SNSCCs based on the extensive clinical experience gained in the context of lung cancer.

\section{EGFR Ex20ins Targeted Therapies}

Treatment for SNSCC varies depending on the stage, comorbidities and tumour type $[5,62,63]$. The most common approach is surgical resection with postoperative radiotherapy. Endoscopic surgery is being increasingly used because less invasive, successful management of this disease remains an unmet clinical need, particularly for advanced stage tumours that have infiltrated the hard palate, external maxillary wall, orbital fat or extraocular muscles, orbital apex, brain or facial soft tissue [5,64]. Overall, the prognosis for SNSCC is poor, averaging $\sim 40 \%$ at 5 years [65]. Although there is no strong data in the literature, patients with de novo SNSCC have almost a twofold increase in mortality compared with those with ISP-associated SNSCC $[17,66,67]$, but this does not translate into any meaningful difference in treatment management.

The fact that a large proportion of ISP-associated SNSCC patients carry EGFR Ex20ins mutations holds promise for new treatment options with EGFR-targeted therapy. In NSCLC, the majority of patients with Ex20ins are resistant to first- and second-generation EGFR TKIs, in contrast to lung cancers with Ex19del or L858R mutations [51,68,69]. Similarly, third-generation inhibitors (such as osimertinib and rociletinib) have shown limited efficacy in pre-clinical and clinical studies in NSCLC patients with EGFR Ex20ins who have failed standard platinum chemotherapy $[52,70,71]$. Despite the general lack of efficacy of first-, second- and third-generation EGFR TKIs, it is notable that small subgroups of Ex20ins patients may benefit from treatment with these agents. For example, it has been shown that NSCLC patients with the rare A763_Y764insFQEA mutation remain sensitive to erlotinib [46]. In the context of SNSCC, Udager et al. have investigated the potential utility of two reversible first-generation inhibitors (gefitinib and erlotinib) and three irreversible second-generation inhibitors (neratinib, afatinib and dacomitinib) in two cell lines derived from SNSCC associated with ISP, SCCNC4 and UM-SCC-112, which carry an S768_D770dupSVD and an N771_H773dupNPH in exon 20, respectively [19]. The authors showed that while ISP-associated SNSCC cell lines were relatively resistant to reversible EGFR inhibitors (IC50 values between $913 \mathrm{nmol} / \mathrm{L}$ and >10,000 nmol/L), irreversible inhibitors, and especially neratinib, had a much more potent growth inhibition (as low as IC50 $143 \mathrm{nmol} / \mathrm{L}$ ) [19]. This result is even more striking when the two ISPassociated SNSCC cell lines are compared to a de novo SNSCC cell line, UM-SCC-33 (EGFR wild-type), that was fully resistant to all the EGFR inhibitors (IC50 > 10,000 $\mathrm{nmol} / \mathrm{L}$ ) [19]. Moreover, neratinib treatment strongly inhibited EGFR activation in SCCNC4 by reducing the phosphorylation of EGFR and its downstream signalling mediators, such as MAPK and AKT [19]. Interestingly, second-generation inhibitors, and in particular the EGFR/HER2 irreversible inhibitor dacomitinib, were also shown to achieve a variable degree of growth inhibition in a panel of EGFR Ex20ins engineered Ba/F3 and NIH-3T3 cell lines [72]. In this study, the authors identified the insertion of glycine at position 770 as a common feature among the dacomitinib-sensitive mutations. Moreover, data from a phase I clinical trial 
(NCT00225121) showed a partial response to dacomitinib in one NSCLC patient with a D770delinsGY in exon 20 supporting the hypothesis of a relationship between specific mutations and corresponding drug sensitivity [73]. Further studies are needed to corroborate these data and provide biological insights into the relationship between drug efficacy and the molecular heterogeneity of Ex20ins mutations in SNSCC patients.

The mutations that have shown a response to first- and second-generation EGFR TKIs previously described are generally rare in SNSCC (as well as in NSCLC), and therefore the majority of EGFR Ex20ins patients are unlikely to benefit from these therapies. In recent years, next-generation agents that are able to more selectively target Ex20ins mutants have undergone pre-clinical studies and clinical trials to evaluate their safety and efficacy in NSCLC patients carrying these mutations. Here, we outline the most clinically advanced candidates that could provide valuable therapeutic options for SNSCC patients harbouring EGFR Ex20ins mutations.

In September 2021, the FDA granted accelerated approval to mobocertinib (TAK-788) for patients with locally advanced or metastatic NSCLC with EGFR Ex20ins mutations whose disease has progressed on or after platinum-based chemotherapy. Mobocertinib is a covalent, irreversible inhibitor that specifically targets EGFR and HER2 [74]. Unlike previously approved reversible and irreversible inhibitors, mobocertinib has shown the ability to bind and inactivate the compact ATP-binding site of EGFR Ex20ins mutants that was shown to be inaccessible to most compounds [75]. Approval was based on results from an international, non-randomized, open-label, multicohort EXCLAIM clinical trial (NCT02716116), which evaluated mobocertinib efficacy in a cohort of 114 NSCLC patients carrying EGFR Ex20ins mutations that have progressed on or after platinum-based chemotherapy [76-78]. Patients were administered with mobocertinib $160 \mathrm{mg}$ orally daily until disease progression or intolerable toxicity. The overall response rate (ORR) was $28 \%$ with a median PFS of 17.5 months. The most common side effect $(>20 \%)$ included diarrhoea, rash and nausea.

Amivantamab, an EGFR and hepatocyte growth factor receptor (MET)-targeted bispecific antibody, has also shown promising efficacy in a multicentre, non-randomized, open label, multicohort CHRYSALIS clinical trial (NCT02609776) involving 81 patients with advanced NSCLC carrying EGFR Ex20ins mutations that have progressed after previous treatment [79]. Patients were treated with amivantamab 1400-1050 mg (based on body weight) once weekly for 4 weeks, then every 2 weeks until disease progression or unacceptable toxicity. The ORR was $40 \%$ with 11.1 months median PFS. The safety profile was manageable. Based on these results, in May 2021, the FDA granted accelerated approval for amivantamab in NSCLC patients with EGFR Ex20ins whose disease has progressed on or after platinum-based chemotherapy.

Poziotinib (HM781-36B), an irreversible EGFR inhibitor, has also been assessed in a number of phase II clinical trials (NCT03066206, NCT03318939) in patients with NSCLC with Ex20ins mutations. As for mobocertinib, poziotinib has shown the ability to access the restricted drug-binding pocket of Ex20ins mutants [52]. However, unlike classical EGFR mutations, Ex20ins mutations can activate EGFR without diminishing ATP affinity versus the wild-type kinase [46]. Indeed, poziotinib is also a potent inhibitor of wild-type EGFR [52], raising concerns that poziotinib may show a narrow therapeutic window, linked to insufficient therapeutic dosing due to toxicity and therefore contributing to short-term tumour responses. In March 2021, the FDA granted poziotinib breakthrough designation status based on promising responses seen across these trials. At that time, there were no approved therapies for the treatment of Ex20ins NSCLC patients. Despite encouraging pre-clinical and clinical results, toxicity remains a major concern for this drug. For instance, in the phase II, open-label, multi-cohort, multicentre ZENITH20 trial (NSCT03318939), a cohort of 115 NSCLC patients that have progressed after previous treatment with a proven EGFR or HER2 Ex20ins mutation who were treated with $16 \mathrm{mg}$ poziotinib once daily achieved an ORR of $14.8 \%$ and a disease control rate (DCR) of $68.7 \%$ with a median PFS of 4.2 months [80]. Grade 3-4 adverse events were reported in $63 \%$ of patients, most 
commonly diarrhoea and skin rash. As a result, $68 \%$ of patients required dose reductions to subtherapeutic doses. These data highlight the limited clinical efficacy of poziotinib and the challenge of targeting EGFR Ex20ins without significant toxicity due to concurrent wild-type inhibition.

Other therapeutics with the ability to target Ex20ins are the covalent, irreversible inhibitor TAS6417 (CLN-081) [81] and the heat shock protein 90 (Hsp90) inhibitor luminespib (NVP-AUY922) [82]. TAS6417 has shown selectivity for Ex20ins over EGFR wild-type in preclinical cell line models indicating a promising wider therapeutic window to target Ex20ins mutants [81]. Luminespib has also shown anti-tumour activity in preclinical studies [83]. Preclinical studies and clinical trials are currently evaluating these compounds in NSCLC patients harbouring EGFR Ex20ins mutations [82,84]. Preliminary results from a phase II clinical trial (NCT04036682) evaluating TAS6417 in a cohort of 37 NSCLC patients with EGFR Ex20ins previously treated with platinum-based therapy showed an acceptable safety profile and encouraging anti-tumour activity [84]. The most common adverse events were rash and diarrhoea, with four patients requiring dose reduction and two patients having to discontinue treatment due to hypersensitivity reactions and pneumonitis [84]. Among the 25 patients with evaluable response, 10 (40\%) had a partial response, $14(56 \%)$ had stable disease and $1(4 \%)$ had progressive disease. Of the patients with partial response and stable disease, 20/24 (83\%) had tumour regression [84]. Luminespib has been evaluated in a phase II clinical trial (NCT01854034) that enrolled patients with late-stage NSCLC carrying EGFR Ex20ins that have progressed after previous treatment [82]. The ORR among the 29 patients was $17 \%$ with a median PFS of 2.9 month [82]. Although luminespib is generally well-tolerated, reversible low-grade ocular toxicity is common. Taken together, the clinical data to date highlight the challenges of targeting Ex20ins mutations with toxicity due to wild-type EGFR inhibition and the high heterogeneity of this class of mutations remaining the main limiting factors.

The potential for combination treatment is a key area of interest. Combinations of antibody-TKI currently being investigated for the treatment of EGFR Ex20ins NSCLC patients include cetuximab, necitumumab and amivantamab in combination with different second- and third-generation EGFR TKIs. Cetuximab is a monoclonal antibody (mAb) that binds to EGFR extracellular domain, preventing ligand binding and blocking receptor activation [85]. After promising results in preclinical models [86], an afatinib and cetuximab combination achieved a partial response (2.7 to 17.6 months) in 3/4 NSCLC patients with EGFR Ex20ins previously treated with platinum-based chemotherapy [87]. A phase II single-arm clinical trial evaluating afatinib and cetuximab in EGFR Ex20ins advanced NSCLC patients is currently ongoing (NCT03727724). Preliminary results from 18 enrolled patients in this trial demonstrated substantial antitumour activity of the afatinib and cetuximab combination with a disease control rate of $59 \%$ at 18 weeks and a response rate of $47 \%$, with manageable toxicity [88]. Similarly, a recent phase I dose escalation study (NCT02496663) evaluating necitumumab, a mAb that binds the extracellular domain of EGFR preventing receptor-ligand binding activation and inducing receptor internalisation [89], and osimertinib in patients with advanced NSCLC and resistant to prior EGFR TKI therapy has shown responses in 2/4 patients carrying Ex20ins, with a median PFS of 5.3 months [90]. In addition, amivantamab is also currently being evaluated in combination with the third-generation EGFR inhibitor lazertinib as part of the combination and doseexpansion cohort of the CHRYSALIS phase I trial (NCT02609776), but no results have been reported yet [91]. The results of these trials are eagerly awaited to determine the impact of combination $\mathrm{mAb}$ and TKI therapy on EGFR Ex20ins tumours.

\section{Lessons from Lung Cancer That Could Be Applied to the Treatment of SNSCC}

The use of EGFR TKIs has improved the outcomes of NSCLC patients carrying EGFR Ex20ins mutations. This has generated interest in the possibility of a similar impact of EGFR targeted therapy in EGFR-mutant SNSCC. Several outstanding questions, however, remain to be addressed. For instance, as described above, many of the compounds that target 
EGFR Ex20ins mutants have limited clinical efficacy, highlighting the challenges associated with the significant molecular heterogeneity of this class of mutations (Figure 2). A recent study from Robichaux et al. has reported an alternative way of predicting patient outcomes following treatment with EGFR inhibitors [68]. This is based on structural and functional changes that are induced by specific mutations [68]. This approach was shown to be more powerful at predicting drug sensitivity compared to the traditional exon-based classification. The authors analysed a panel of 76 cell lines harbouring EGFR mutations (spanning exons 18 to 21), which was subjected to treatment with 18 different EGFR TKIs (including first-, second-, third-generation and Ex20ins TKIs). They found that Ex20ins mutants could be divided into two subgroups based on differential drug sensitivity: (i) classical-like mutations that were distant from the ATP-binding pocket (insertions in the $\alpha \mathrm{C}$-helix) and (ii) insertions in the loop at the C-terminal end of the $\alpha$ C-helix (Ex20ins-L) [68]. Insertions in the $\alpha \mathrm{C}$-helix showed high sensitivity to all the inhibitors tested, while Ex20ins-L mutations were sensitive only to selective TKIs (poziotinib and TAS6417). Moreover, even within the Ex20ins-L mutations, some degree of heterogeneity was observed that allowed a further sub-classification into near- and far-loop Ex20ins mutants, with the near-loop mutations showing more sensitivity to second-generation and Ex20ins TKIs compared to the Ex20ins far-loop mutants [68]. Given these data, this structure-based approach to classification of drug response has the potential to improve the prediction of effective treatment options for patients carrying rare EGFR mutations.

With multiple new TKIs and mAb that target EGFR Ex20ins under investigation, which drug to give and in which line of treatment remain key questions in clinical management. Currently, the two agents (amivantamab and mobocertinib) used in the clinic for the treatment of NSCLC carrying EGFR Ex20ins have been granted approval from the FDA as second-line therapy in patients that have progressed on platinum-based chemotherapy. The trials to evaluate the use of these agents as first-line therapies for the treatment of EGFR Ex20ins mutant NSCLC are ongoing. A randomized first-line study of amivantamab plus chemotherapy versus chemotherapy alone in EGFR Ex20ins is ongoing (PAPILLON, NCT04538664). Moreover, the phase III EXCLAIM-2 clinical trial is evaluating the efficacy of mobocertinib versus platinum-doublet chemotherapy among treatment-naïve patients (NCT04129502). The outcome of these studies will be particularly useful to inform future clinical studies in the context of previously untreated SNSCC patients who harbour EGFR Ex20ins mutations. Another unresolved question is whether the treatment of SNSCC EGFR Ex20ins tumours with targeted therapies will achieve durable clinical response or instead will result in the development of acquired resistance mechanisms, as observed in NSCLC patients. Taking lessons from EGFR inhibitor therapy in NSCLC, several mechanisms of resistance can be predicted in the context of SNSCC. The most common mechanisms include on-target EGFR secondary mutations, compensatory bypass pathway activation, the acquisition of an epithelial to mesenchymal transition (EMT) phenotype and the presence of drug-tolerant persister (DTP) cells in the heterogeneous tumour population [92]. Specifically, clinical mechanisms of resistance have been reported for some of the Ex20ins inhibitors mentioned before [93]. Evidence from the use of poziotinib in NSCLC patients and in preclinical models suggests drug resistance can be driven by the acquisition of secondary on-target mutations in EGFR, such as the T790M gatekeeper and C797S point mutation [52,93], which have been extensively studied in the context of acquired resistance to first- and third-generation EGFR inhibitors, respectively [94-96]. Both poziotinib and mobocertinib have shown the ability to covalently bind to the EGFR C797 cysteine residue, indicating that point mutations in this amino acid may confer Ex20ins TKIs resistance [52,97]. In addition, co-occurring mutations in KRAS and ErbB4 have also been shown to drive resistance to poziotinib in genetically engineered mouse models harbouring tumours expressing EGFR Ex20ins (D770insNPG) [93]. Moreover, mutations in MAPK2 and PIK3CA and amplifications in MET and cyclin-dependent kinase 6 (CDK6) have also been identified in Ex20ins NSCLC patient biopsies that progressed after poziotinib treatment [93]. Interestingly, $M E T$ and $C D K 6$ amplifications are known mechanisms of resistance to first- 
and third-generation EGFR TKIs and can be targeted to overcome resistance to Ex20ins inhibitors [98,99].

In the context of ISP-associated SNSCC, little is known about the oncogenic mechanisms driving the malignant progression from sinonasal papillomas to carcinoma. A comprehensive assessment of the molecular landscape of mutations and copy number alterations in papilloma-associated SNSCC utilising targeted next-generation DNA sequencing of frequently altered cancer genes was performed by Brown et al. [100]. The authors confirmed the presence of recurrent EGFR mutations in 21/24 ISP-associated SNSCC [100]. Interestingly, EGFR mutations were mutually exclusive with mutations in $K R A S$, which is commonly found in OSP-associated SNSCC [100]. In addition, recurrent mutations were found in the tumour suppressor TP53 (in 16/24 cases) and in the cyclin-dependent kinase inhibitor 2A (CDKN2A) (in 10/24 cases) in ISP-associated SNSCC [100]. Notably, these inactivating mutations were not observed in the matched ISP tumours suggesting that these alterations may be early molecular events in the malignant progression to carcinoma. Activating mutations (4/24) and copy number gain $(2 / 24)$ in PIK3CA were also shown to co-occur with EGFR mutations in ISP-associated SNSCC [100]. These data were confirmed by an independent study from Uchi et al. in a smaller cohort that also reported high prevalence of co-occurring mutations in neurofibromin 1 (NF1) in EGFR mutated ISP-associated SNSCC tumours [101]. Interestingly, TP53 and CDKN2A have also been identified as common co-occurring alterations in EGFR ex20ins NSCLC tumours [102], while a E545K mutation in PIK3CA was detected in 1/20 Ex20ins NSCLC patient that progressed after poziotinib treatment [93]. It is plausible that these co-occurring genomic aberrations may play a role in driving intrinsic and acquired resistance to EGFR TKI therapy in SNSCC.

EMT has also been shown to confer resistance to clinically approved EGFR inhibitors that target classical EGFR mutations in NSCLC $[103,104]$ and has been indirectly identified as a potential mechanism of resistance to poziotinib in NSCLC cell lines, HCC4006 and HCC827, harbouring classical EGFR mutations (Ex19del) [52]. Subjecting these two cell lines to chronic escalating dose treatment led to the development of erlotinib resistance and EMT. These EMT-driven, erlotinib-resistant cells also showed resistance to poziotinib, indicating that poziotinib may be susceptible to similar mechanisms of acquired resistance as other EGFR TKIs that target classical EGFR mutations [52]. Finally, it is now well established that the subpopulation of DTP cells that remain viable in the presence of anti-cancer treatments despite not harbouring classic genetic mutations can contribute to acquired resistance to first- and third-generation EGFR TKIs in NSCLC cell line models [92,105-107]. This knowledge from classical EGFR mutations in lung cancer is important as it allows us to anticipate the potential routes of drug resistance to EGFR Ex20ins inhibitors in other clinical settings, such as in SNSCC. A better understanding of the resistance mechanisms arising following EGFR TKIs treatment may facilitate the identification of new therapeutics that could be used as salvage therapy.

\section{Conclusions}

The incidence of EGFR Ex20ins mutations in ISP and ISP-associated SNSCC tumours implicates a prominent role for activating EGFR mutations in these diseases and opens up an exciting opportunity for treatment with EGFR targeted therapies. Although this class of mutations is associated with poorer response to first-, second- and third-generation EGFR TKIs compared to classical EGFR mutations, a number of next-generation EGFR targeted agents have recently been approved for the treatment of NSCLC tumours harbouring Ex20ins or are currently undergoing clinical evaluation $[79,80,82,84]$. However, there is evidence in lung cancer of a poor therapeutic index in some of these inhibitors and rapid development of acquired resistance. Further research is therefore needed to better understand whether SNSCC patients with Ex20ins will respond to these inhibitors but also to develop more insights into the spectrum of biological mechanisms of drug resistance. 


\begin{abstract}
Author Contributions: Conceptualization, L.P., M.A.H. and P.H.H.; investigation, L.P. and V.N.C.; data curation, L.P., V.N.C., M.A.H. and P.H.H.; writing-original draft preparation, L.P.; writingreview and editing, L.P., V.N.C., M.A.H. and P.H.H.; supervision, M.A.H. and P.H.H.; funding acquisition, M.A.H. and P.H.H. All authors have read and agreed to the published version of the manuscript.
\end{abstract}

Funding: This research was funded by: Cancer Research UK (C36478/A19281), Fondos de Investigación Sanitaria (FIS) (PI19/00191), Centro de Investigación Biomédica en Red de Cancer (CIBERONC) (CB16/12/00390) and Ayudas a Grupos PCTI Principado de Asturias (IDI2018/155).

Conflicts of Interest: The authors declare no conflict of interest.

\title{
References
}

1. Franchi, A. Pathology of Sinonasal Tumors and Tumor-like Lesions, 1st ed.; Springer: Cham, Switzerland, 2020. [CrossRef]

2. Ansa, B.; Goodman, M.; Ward, K.; Kono, S.A.; Owonikoko, T.K.; Higgins, K.; Beitler, J.J.; Grist, W.; Wadsworth, T.; El-Deiry, M.; et al. Paranasal sinus squamous cell carcinoma incidence and survival based on Surveillance, Epidemiology, and End Results data, 1973 to 2009. Cancer 2013, 119, 2602-2610. [CrossRef] [PubMed]

3. Sanghvi, S.; Khan, M.N.; Patel, N.R.; Bs, S.Y.; Baredes, S.; Eloy, J.A. Epidemiology of sinonasal squamous cell carcinoma: A comprehensive analysis of 4994 patients. Laryngoscope 2013, 124, 76-83. [CrossRef] [PubMed]

4. $\quad$ EI-Naggar, A.K.; Chan, J.K.C.; Grandis, J.R.; Takata, T.; Slootweg, P.J. WHO Classification of Head and Neck Tumours. In WHO Classification of Head and Neck Tumors 2017; International Agency for Research on Cancer (IARC): Lyon, France, 2017.

5. Llorente, J.L.; López, F.; Suárez, C.; Hermsen, M.A. Sinonasal carcinoma: Clinical, pathological, genetic and therapeutic advances. Nat. Rev. Clin. Oncol. 2014, 11, 460-472. [CrossRef]

6. Vazquez, A.; Khan, M.N.; Blake, D.M.; Patel, T.D.; Baredes, S.; Eloy, J.A. Sinonasal squamous cell carcinoma and the prognostic implications of its histologic variants: A population-based study. Int. Forum Allergy Rhinol. 2014, 5, 85-91. [CrossRef] [PubMed]

7. Dutta, R.; Ba, P.M.D.; Svider, P.F.; Liu, J.K.; Baredes, S.; Eloy, J.A. Sinonasal malignancies: A population-based analysis of site-specific incidence and survival. Laryngoscope 2015, 125, 2491-2497. [CrossRef]

8. Haerle, S.K.; Gullane, P.J.; Witterick, I.J.; Zweifel, C.; Gentili, F. Sinonasal carcinomas: Epidemiology, pathology, and management. Neurosurg. Clin. N. Am. 2013, 24, 39-49. [CrossRef]

9. Cantu, G.; Solero, C.L.; Miceli, R.; Mattana, F.; Riccio, S.; Colombo, S.; Pompilio, M.; Lombardo, G.; Formillo, P.; Quattrone, P. Anterior craniofacial resection for malignant paranasal tumors: A monoinstitutional experience of 366 cases. Head Neck 2011, 34 , 78-87. [CrossRef]

10. Kim, S.A.; Chung, Y.-S.; Lee, B.J. Recurrence patterns of sinonasal cancers after a 5-year disease-free period. Laryngoscope 2019, 129, 2451-2457. [CrossRef]

11. Hayes, R.; Kardaun, J.; De Bruyn, A. Tobacco use and sinonasal cancer: A case-control study. Br. J. Cancer 1987, 56, 843-846. [CrossRef] [PubMed]

12. Bishop, J.A.; Guo, T.W.; Smith, D.F.; Wang, H.; Ogawa, T.; Pai, S.I.; Westra, W.H. Human Papillomavirus-related Carcinomas of the Sinonasal Tract. Am. J. Surg. Pathol. 2013, 37, 185-192. [CrossRef]

13. Elgart, K.; Faden, D.L. Sinonasal Squamous Cell Carcinoma: Etiology, Pathogenesis, and the Role of Human Papilloma Virus. Curr. Otorhinolaryngol. Rep. 2020, 8, 111-119. [CrossRef]

14. Bishop, J.A.; Andreasen, S.; Hang, J.; Bullock, M.J.; Chen, T.Y.; Franchi, A.; Garcia, J.J.; Gnepp, D.R.; Gomez-Fernandez, C.R.; Ihrler, S.; et al. HPV-related Multiphenotypic Sinonasal Carcinoma: An Expanded Series of 49 Cases of the Tumor Former-ly Known as HPV-related Carcinoma with Adenoid Cystic Carcinoma-like Features. Am. J. Surg. Pathol. 2017, 41, 1690-1701. [CrossRef] [PubMed]

15. Bishop, J.A. OSPs and ESPs and ISPs, Oh My! An Update on Sinonasal (Schneiderian) Papillomas. Head Neck Pathol. 2017, 11, 269-277. [CrossRef]

16. Re, M.; Gioacchini, F.M.; Bajraktari, A.; Tomasetti, M.; Kaleci, S.; Rubini, C.; Bertini, A.; Magliulo, G.; Pasquini, E. Malignant transformation of sinonasal inverted papilloma and related genetic alterations: A systematic review. Eur. Arch. Oto-Rhino-Laryngol. 2017, 274, 2991-3000. [CrossRef]

17. Nudell, J.; Chiosea, S.; Thompson, L.D.R. Carcinoma ex-Schneiderian papilloma (malignant transformation): A clinico-pathologic and immunophenotypic study of 20 cases combined with a comprehensive review of the literature. Head Neck Pathol. 2014, 8, 269-286. [CrossRef] [PubMed]

18. Maisch, S.; Mueller, S.; Traxdorf, M.; Weyerer, V.; Stoehr, R.; Iro, H.; Hartmann, A.; Agaimy, A. Sinonasal papillomas: A single centre experience on 137 cases with emphasis on malignant transformation and EGFR/KRAS status in "carcinoma ex papilloma". Ann. Diagn. Pathol. 2020, 46, 151504. [CrossRef]

19. Udager, A.M.; Rolland, D.C.M.; McHugh, J.B.; Betz, B.L.; Murga-Zamalloa, C.; Carey, T.; Marentette, L.J.; Hermsen, M.A.; DuRoss, K.E.; Lim, M.; et al. High-Frequency Targetable EGFR Mutations in Sinonasal Squamous Cell Carcinomas Arising from Inverted Sinonasal Papilloma. Cancer Res. 2015, 75, 2600-2606. [CrossRef] 
20. Sahnane, N.; Ottini, G.; Turri-Zanoni, M.; Furlan, D.; Battaglia, P.; Karligkiotis, A.; Albeni, C.; Cerutti, R.; Mura, E.; Chiaravalli, A.M.; et al. Comprehensive analysis of HPV infection, EGFR exon 20 mutations and LINE1 hypomethylation as risk factors for malignant transformation of sinonasal-inverted papilloma to squamous cell carcinoma. Int. J. Cancer 2018, 144, $1313-1320$. [CrossRef] [PubMed]

21. Udager, A.M.; McHugh, J.B.; Betz, B.L.; Montone, K.T.; Livolsi, V.A.; Seethala, R.R.; Yakirevich, E.; Iwenofu, O.H.; Perez-Ordonez, B.; DuRoss, K.E.; et al. Activating KRAS mutations are characteristic of oncocytic sinonasal papilloma and associated sinonasal squamous cell carcinoma. J. Pathol. 2016, 239, 394-398. [CrossRef]

22. Purba, E.; Saita, E.; Maruyama, I. Activation of the EGF Receptor by Ligand Binding and Oncogenic Mutations: The 'Rota-tion Model'. Cells 2017, 6, 13. [CrossRef]

23. Yarden, Y.; Sliwkowski, M.X. Untangling the ErbB signalling network. Nat. Rev. Mol. Cell Biol. 2001, 2, 127-137. [CrossRef] [PubMed]

24. Lemmon, M.A.; Schlessinger, J. Cell Signaling by Receptor Tyrosine Kinases. Cell 2010, 141, 1117-1134. [CrossRef]

25. Schlessinger, J. Receptor Tyrosine Kinases: Legacy of the First Two Decades. Cold Spring Harb. Perspect. Biol. 2014, 6, a008912. [CrossRef] [PubMed]

26. Miettinen, P.J.; Berger, J.E.; Meneses, J.; Phung, Y.; Pedersen, R.A.; Werb, Z.; Derynck, R. Epithelial immaturity and multiorgan failure in mice lacking epidermal growth factor receptor. Nature 1995, 376, 337-341. [CrossRef]

27. Sibilia, M.; Wagner, E.F. Strain-dependent epithelial defects in mice lacking the EGF receptor. Science 1995, 269, 234-238. [CrossRef]

28. Huang, P.H.; Xu, A.M.; White, F.M. Oncogenic EGFR Signaling Networks in Glioma. Sci. Signal. 2009, 2, re6. [CrossRef]

29. Hynes, N.E.; MacDonald, G. ErbB receptors and signaling pathways in cancer. Curr. Opin. Cell Biol. 2009, 21, 177-184. [CrossRef] [PubMed]

30. Zandi, R.; Larsen, A.B.; Andersen, P.; Stockhausen, M.T.; Poulsen, H.S. Mechanisms for oncogenic activation of the epi-dermal growth factor receptor. Cell. Signal. 2007, 19, 2013-2023. [CrossRef]

31. Brennan, C.W.; Verhaak, R.G.W.; McKenna, A.; Campos, B.; Noushmehr, H.; Salama, S.R.; Zheng, S.; Chakravarty, D.; Sanborn, J.Z.; Berman, S.H.; et al. The Somatic Genomic Landscape of Glioblastoma. Cell 2013, 155, 462-477. [CrossRef] [PubMed]

32. Jeuken, J.; Sijben, A.; Alenda, C.; Rijntjes, J.; Dekkers, M.; Boots-Sprenger, S.; McLendon, R.; Wesseling, P. Robust detection of EGFR copy number changes and EGFR variant III: Technical aspects and relevance for glioma diagnostics. Brain Pathol. 2009, 19, 661-671. [CrossRef]

33. Cerami, E.; Gao, J.; Dogrusoz, U.; Gross, B.E.; Sumer, S.O.; Aksoy, B.A.; Jacobsen, A.; Byrne, C.J.; Heuer, M.L.; Larsson, E.; et al. The cBio cancer genomics portal: An open platform for exploring multidimensional cancer genomics data. Cancer Discov. 2012, 2, 401-404. [CrossRef] [PubMed]

34. Lee, J.; Kotliarova, S.; Kotliarov, Y.; Li, A.; Su, Q.; Donin, N.M.; Pastorino, S.; Purow, B.W.; Christopher, N.; Zhang, W.; et al. Tumor stem cells derived from glioblastomas cultured in bFGF and EGF more closely mirror the phenotype and genotype of primary tumors than do serum-cultured cell lines. Cancer Cell 2006, 9, 391-403. [CrossRef] [PubMed]

35. Ji, H.; Zhao, X.; Yuza, Y.; Shimamura, T.; Li, D.; Protopopov, A.; Jung, B.L.; McNamara, K.; Xia, H.; Glatt, K.A.; et al. Epidermal growth factor receptor variant III mutations in lung tumorigenesis and sensitivity to tyrosine kinase in-hibitors. Proc. Natl. Acad. Sci. USA 2006, 103, 7817-7822. [CrossRef]

36. Chagoya, G.; Kwatra, S.G.; Nanni, C.W.; Roberts, C.; Phillips, S.; Nullmeyergh, S.; Gilmore, S.P.; Spasojevic, I.; Corcoran, D.L.; Young, C.C.; et al. Efficacy of osimertinib against EGFRvIII+ glioblastoma. Oncotarget 2020, 11, 2074-2082. [CrossRef]

37. Kwatra, M.M. A Rational Approach to Target the Epidermal Growth Factor Receptor in Glioblastoma. Curr. Cancer Drug Targets 2017, 17, 290-296. [CrossRef]

38. Pakkala, S.; Ramalingam, S.S. Personalized therapy for lung cancer: Striking a moving target. JCI Insight 2018, 3 , e120858. [CrossRef]

39. D'Angelo, S.P.; Pietanza, M.C.; Johnson, M.L.; Riely, G.J.; Miller, V.A.; Sima, C.S.; Zakowski, M.F.; Rusch, V.; Ladanyi, M.; Kris, M.G. Incidence of EGFR Exon 19 Deletions and L858R in Tumor Specimens from Men and Cigarette Smokers With Lung Adenocarcinomas. J. Clin. Oncol. 2011, 29, 2066-2070. [CrossRef]

40. Kobayashi, Y.; Mitsudomi, T. Not all epidermal growth factor receptor mutations in lung cancer are created equal: Perspec-tives for individualized treatment strategy. Cancer Sci. 2016, 107, 1179-1186. [CrossRef]

41. Paez, J.G.; Jänne, P.A.; Lee, J.C.; Tracy, S.; Greulich, H.; Gabriel, S.; Herman, P.; Kaye, F.J.; Lindeman, N.; Boggon, T.J.; et al. EGFR Mutations in Lung Cancer: Correlation with Clinical Response to Gefitinib Therapy. Science 2004, 304, 1497-1500. [CrossRef] [PubMed]

42. Harrison, P.T.; Vyse, S.; Huang, P.H. Rare epidermal growth factor receptor (EGFR) mutations in non-small cell lung cancer. Semin. Cancer Biol. 2020, 61, 167-179. [CrossRef]

43. Yasuda, H.; Kobayashi, S.; Costa, D. EGFR exon 20 insertion mutations in non-small-cell lung cancer: Preclinical data and clinical implications. Lancet Oncol. 2012, 13, e23-e31. [CrossRef]

44. Arcila, M.E.; Nafa, K.; Chaft, J.; Rekhtman, N.; Lau, C.; Reva, B.; Zakowski, M.F.; Kris, M.; Ladanyi, M. EGFR Exon 20 Insertion Mutations in Lung Adenocarcinomas: Prevalence, Molecular Heterogeneity, and Clinicopathologic Characteristics. Mol. Cancer Ther. 2013, 12, 220-229. [CrossRef] 
45. Oxnard, G.R.; Lo, P.C.; Nishino, M.; Dahlberg, S.; Lindeman, N.I.; Butaney, M.; Jackman, D.M.; Johnson, B.E.; Jänne, P.A. Natural History and Molecular Characteristics of Lung Cancers Harboring EGFR Exon 20 Insertions. J. Thorac. Oncol. 2013, 8, 179-184. [CrossRef]

46. Yasuda, H.; Park, E.; Yun, C.-H.; Sng, N.J.; Lucena-Araujo, A.R.; Yeo, W.-L.; Huberman, M.S.; Cohen, D.W.; Nakayama, S.; Ishioka, K.; et al. Structural, Biochemical, and Clinical Characterization of Epidermal Growth Factor Receptor (EGFR) Exon 20 Insertion Mutations in Lung Cancer. Sci. Transl. Med. 2013, 5, 216ra177. [CrossRef]

47. Vyse, S.; Huang, P.H. Targeting EGFR exon 20 insertion mutations in non-small cell lung cancer. Signal Transduct. Target. Ther. 2019, 4, 51. [CrossRef]

48. Beau-Faller, M.; Prim, N.; Ruppert, A.M.; Nanni-Metéllus, I.; Lacave, R.; Lacroix, L.; Escande, F.; Lizard, S.; Pretet, J.L.; Rouquette, I.; et al. Rare EGFR exon 18 and exon 20 mutations in non-small-cell lung cancer on 10117 patients: A multicen-tre observational study by the French ERMETIC-IFCT network. Ann. Oncol. 2014, 25, 126. [CrossRef] [PubMed]

49. Naidoo, J.; Sima, C.S.; Rodriguez, K.; Busby, N.; Nafa, K.; Ladanyi, M.; Riely, G.J.; Kris, M.; Arcila, M.E.; Yu, H.A. Epidermal growth factor receptor exon 20 insertions in advanced lung adenocarcinomas: Clinical outcomes and response to erlotinib. Cancer 2015, 121, 3212-3220. [CrossRef] [PubMed]

50. Sequist, L.V.; Waltman, B.A.; Dias-Santagata, D.; Digumarthy, S.; Turke, A.B.; Fidias, P.; Bergethon, K.; Shaw, A.T.; Gettinger, S.; Cosper, A.K.; et al. Genotypic and Histological Evolution of Lung Cancers Acquiring Resistance to EGFR Inhibitors. Sci. Transl. Med. 2011, 3, 75ra26. [CrossRef]

51. Yang, J.C.-H.; Sequist, L.V.; Geater, S.L.; Tsai, C.-M.; Mok, T.; Schuler, M.; Yamamoto, N.; Yu, C.-J.; Ou, S.-H.I.; Zhou, C.; et al. Clinical activity of afatinib in patients with advanced non-small-cell lung cancer harbouring uncommon EGFR mutations: A combined post-hoc analysis of LUX-Lung 2, LUX-Lung 3, and LUX-Lung 6. Lancet Oncol. 2015, 16, 830-838. [CrossRef]

52. Robichaux, J.P.; Elamin, Y.Y.; Tan, Z.; Carter, B.W.; Zhang, S.; Liu, S.; Li, S.; Chen, T.; Poteete, A.; Estrada-Bernal, A.; et al. Mechanisms and clinical activity of an EGFR and HER2 exon 20-selective kinase inhibitor in non-small cell lung cancer. Nat. Med. 2018, 24, 638-646. [CrossRef]

53. Barnes, L. Schneiderian Papillomas and Nonsalivary Glandular Neoplasms of the Head and Neck. Mod. Pathol. 2002, 15, 279-297. [CrossRef]

54. Stransky, N.; Egloff, A.M.; Tward, A.D.; Kostic, A.D.; Cibulskis, K.; Sivachenko, A.; Kryukov, G.V.; Lawrence, M.S.; Sougnez, C.; McKenna, A.; et al. The Mutational Landscape of Head and Neck Squamous Cell Carcinoma. Science 2011, 333, 1157-1160. [CrossRef] [PubMed]

55. Forbes, S.A.; Beare, D.; Boutselakis, H.; Bamford, S.; Bindal, N.; Tate, J.; Cole, C.G.; Ward, S.; Dawson, E.; Ponting, L.; et al. COSMIC: Somatic cancer genetics at high-resolution. Nucleic Acids Res. 2016, 45, D777-D783. [CrossRef]

56. Cabal, V.; Menendez, M.; Vivanco, B.; Potes-Ares, S.; Riobello, C.; Suarez-Fernandez, L.; Garcia-Marin, R.; Blanco-Lorenzo, V.; Lopez, F.; Alvarez-Marcos, C.; et al. EGFR mutation and HPV infection in sinonasal inverted papilloma and squamous cell carcinoma. Rhinol. J. 2020, 58, 368-376. [CrossRef]

57. Sasaki, E.; Nishikawa, D.; Hanai, N.; Hasegawa, Y.; Yatabe, Y. Sinonasal squamous cell carcinoma and EGFR mutations: A molecular footprint of a benign lesion. Histopathology 2018, 73, 953-962. [CrossRef] [PubMed]

58. Wang, H.; Li, H.; Hu, L.; Zhou, J.; Zhai, C.; Wang, D.; Sun, X. EGFR and KRAS mutations in Chinese patients with sinonasal inverted papilloma and oncocytic papilloma. Histopathology 2019, 75, 274-281. [CrossRef]

59. Udager, A.; McHugh, J.; Goudsmit, C.; Weigelin, H.; Lim, M.; Elenitoba-Johnson, K.; Betz, B.; Carey, T.; Brown, N. Human papillomavirus (HPV) and somatic EGFR mutations are essential, mutually exclusive oncogenic mechanisms for inverted sinonasal papillomas and associated sinonasal squamous cell carcinomas. Ann. Oncol. 2017, 29, 466-471. [CrossRef] [PubMed]

60. Hongo, T.; Yamamoto, H.; Jiromaru, R.; Nozaki, Y.; Yasumatsu, R.; Hashimoto, K.; Yoneda, R.; Sugii, A.; Taguchi, K.; Masuda, M.; et al. Clinicopathologic Significance of EGFR Mutation and HPV Infection in Sinonasal Squamous Cell Carcinoma. Am. J. Surg. Pathol. 2020, 45, 108-118. [CrossRef]

61. Cho, J.; Kim, S.; Du, J.; Meyerson, M. Autophosphorylation of the carboxyl-terminal domain is not required for oncogenic transformation by lung-cancer derived EGFR mutants. Int. J. Cancer 2018, 143, 679-685. [CrossRef]

62. Ferrari, M.; Taboni, S.; Carobbio, A.; Emanuelli, E.; Maroldi, R.; Bossi, P.; Nicolai, P. Sinonasal Squamous Cell Carcinoma, a Narrative Reappraisal of the Current Evidence. Cancers 2021, 13, 2835. [CrossRef]

63. Farrell, N.F.; Mace, J.C.; Detwiller, K.Y.; Li, R.; Andersen, P.E.; Smith, T.L.; Clayburgh, D.R.; Geltzeiler, M. Predictors of survival outcomes in sinonasal squamous cell carcinoma: An analysis of the National Cancer Database. Int. Forum Allergy Rhinol. 2020, 11, 1001-1011. [CrossRef] [PubMed]

64. Lewis, J.S. Sinonasal Squamous Cell Carcinoma: A Review with Emphasis on Emerging Histologic Subtypes and the Role of Human Papillomavirus. Head Neck Pathol. 2016, 10, 60-67. [CrossRef]

65. Turner, J.H.; Reh, D.D. Incidence and survival in patients with sinonasal cancer: A historical analysis of population-based data. Head Neck 2011, 34, 877-885. [CrossRef]

66. Lee, J.J.; Peterson, A.M.; Embry, T.W.; Wamkpah, N.S.; Kallogjeri, D.; Doering, M.M.; Schneider, J.S.; Klatt-Cromwell, C.N.; Pipkorn, P. Survival Outcomes of De Novo vs Inverted Papilloma-Associated Sinonasal Squamous Cell Carcinoma: A Sys-tematic Review and Meta-analysis. JAMA Otolaryngol. Head Neck Surg. 2021, 147, 350-359. [CrossRef] [PubMed] 
67. Nishikawa, D.; Sasaki, E.; Suzuki, H.; Beppu, S.; Sawabe, M.; Terada, H.; Sone, M.; Hanai, N. Treatment outcome and pattern of recurrence of sinonasal squamous cell carcinoma with EGFR-mutation and human papillomavirus. J. Cranio-Maxillofacial Surg. 2021, 49, 494-500. [CrossRef]

68. Robichaux, J.P.; Le, X.; Vijayan, R.S.K.; Hicks, J.K.; Heeke, S.; Elamin, Y.Y.; Lin, H.Y.; Udagawa, H.; Skoulidis, F.; Tran, H.; et al Structure-based classification predicts drug response in EGFR-mutant NSCLC. Nature 2021, 597, 732-737. [CrossRef] [PubMed]

69. Sequist, L.V.; Besse, B.; Lynch, T.J.; Miller, V.A.; Wong, K.K.; Eaton, B.G.; Zacharchuk, C.; Freyman, A.; Powell, C.; Ananthakrishnan, R.; et al. Neratinib, an irreversible pan-ErbB receptor tyrosine kinase inhibitor: Results of a phase II trial in patients with advanced non-small-cell lung cancer. J. Clin. Oncol. 2010, 28, 3076-3083. [CrossRef]

70. Kim, T.; Ock, C.-Y.; Kim, M.; Kim, S.; Keam, B.; Kim, Y.; Kim, D.-W.; Lee, J.-S.; Heo, D. Phase II study of osimertinib in NSCLC patients with EGFR exon 20 insertion mutation: A multicenter trial of the Korean Cancer Study Group (LU17-19). Ann. Oncol. 2019, 30, v628. [CrossRef]

71. Yang, J.C.-H.; Reckamp, K.L.; Kim, Y.C.; Novello, S.; Smit, E.F.; Lee, J.S.; Su, W.C.; Akerley, W.L.; Blakely, C.M.; Groen, H.J.M.; et al. Efficacy and Safety of Rociletinib Versus Chemotherapy in Patients with EGFR-Mutated NSCLC: The Results of TIGER-3, a Phase 3 Randomized Study. JTO Clin. Res. Rep. 2021, 2, 100114. [CrossRef]

72. Kosaka, T.; Tanizaki, J.; Paranal, R.M.; Endoh, H.; Lydon, C.; Capelletti, M.; Repellin, C.E.; Choi, J.; Ogino, A.; Calles, A.; et al Response heterogeneity of EGFR and HER2 exon 20 insertions to covalent EGFR and HER2 inhibitors. Cancer Res. 2017, 77, 2712-2721. [CrossRef]

73. Jänne, P.A.; Boss, D.S.; Camidge, D.R.; Britten, C.D.; Engelman, J.A.; Garon, E.B.; Guo, F.; Wong, S.; Liang, J.; Letrent, S.; et al. Phase I Dose-Escalation Study of the Pan-HER Inhibitor, PF299804, in Patients with Advanced Malignant Solid Tumors. Clin. Cancer Res. 2011, 17, 1131-1139. [CrossRef]

74. Janne, P.A.; Neal, J.W.; Camidge, D.R.; Spira, A.I.; Piotrowska, Z.; Horn, L.; Costa, D.B.; Tsao, A.S.; Patel, J.D.; Gadgeel, S.M.; et al. Antitumor activity of TAK-788 in NSCLC with EGFR exon 20 insertions. J. Clin. Oncol. 2019, 37, 9007. [CrossRef]

75. Doebele, R.C.; Riely, G.J.; Spira, A.I.; Horn, L.; Piotrowska, Z.; Costa, D.B.; Neal, J.W.; Zhang, S.; Reichmann, W.; Kerstein, D.; et al. First report of safety, PK, and preliminary antitumor activity of the oral EGFR/HER2 exon 20 inhibitor TAK-788 (AP32788) in non-small cell lung cancer (NSCLC). J. Clin. Oncol. 2018, 36, 9015. [CrossRef]

76. Riely, G.J.; Neal, J.W.; Camidge, D.R.; Spira, A.I.; Piotrowska, Z.; Costa, D.B.; Tsao, A.S.; Patel, J.D.; Gadgeel, S.M.; Bazhenova, L.; et al. Activity and Safety of Mobocertinib (TAK-788) in Previously Treated Non-Small Cell Lung Cancer with EGFR Exon 20 Insertion Mutations from a Phase I/II Trial. Cancer Discov. 2021, 11, 1688-1699. [CrossRef] [PubMed]

77. Ramalingam, S.S.; Zhou, C.; Kim, T.M.; Kim, S.-W.; Yang, J.C.-H.; Riely, G.J.; Mekhail, T.; Nguyen, D.; Campelo, M.R.G.; Felip, E.; et al. Mobocertinib (TAK-788) in EGFR exon 20 insertion (ex20ins)+ metastatic NSCLC (mNSCLC): Additional results from platinum-pretreated patients (pts) and EXCLAIM cohort of phase 1/2 study. J. Clin. Oncol. 2021, 39, 9014. [CrossRef]

78. Zhou, C.; Ramalingam, S.S.; Kim, T.M.; Kim, S.-W.; Yang, J.C.-H.; Riely, G.J.; Mekhail, T.; Nguyen, D.; Campelo, M.R.G.; Felip, E.; et al. Treatment Outcomes and Safety of Mobocertinib in Platinum-Pretreated Patients with EGFR Exon 20 Insertion-Positive Metastatic Non-Small Cell Lung Cancer. JAMA Oncol. 2021, 7, e214761. [CrossRef]

79. Park, K.; Haura, E.B.; Leighl, N.B.; Mitchell, P.; Shu, C.A.; Girard, N.; Viteri, S.; Han, J.-Y.; Kim, S.-W.; Lee, C.K.; et al. Amivantamab in EGFR Exon 20 Insertion-Mutated Non-Small-Cell Lung Cancer Progressing on Platinum Chemotherapy: Initial Results from the CHRYSALIS Phase I Study. J. Clin. Oncol. 2021, 39, 3391-3402. [CrossRef]

80. Park, K.; John, T.; Kim, S.-W.; Lee, J.S.; Shu, C.A.; Kim, D.-W.; Ramirez, S.V.; Spira, A.I.; Sabari, J.K.; Han, J.-Y.; et al. Amivantamab (JNJ-61186372), an anti-EGFR-MET bispecific antibody, in patients with EGFR exon 20 insertion (exon20ins)-mutated non-small cell lung cancer (NSCLC). J. Clin. Oncol. 2020, 38, 9512. [CrossRef]

81. Udagawa, H.; Hasako, S.; Ohashi, A.; Fujioka, R.; Hakozaki, Y.; Shibuya, M.; Abe, N.; Komori, T.; Haruma, T.; Terasaka, M.; et al. TAS6417/CLN-081 is a pan-mutation-selective EGFR tyrosine kinase inhibitor with a broad spectrum of preclinical activity against clinically relevant EGFR mutations. Mol. Cancer Res. 2019, 17, 2233-2243. [CrossRef]

82. Piotrowska, Z.; Costa, D.; Oxnard, G.; Huberman, M.; Gainor, J.; Lennes, I.; Muzikansky, A.; Shaw, A.; Azzoli, C.; Heist, R.; et al Activity of the Hsp90 inhibitor luminespib among non-small-cell lung cancers harboring EGFR exon 20 insertions. Ann. Oncol. 2018, 29, 2092-2097. [CrossRef]

83. Jorge, S.E.; Lucena-Araujo, A.R.; Yasuda, H.; Piotrowska, Z.; Oxnard, G.R.; Rangachari, D.; Huberman, M.S.; Sequist, L.V.; Kobayashi, S.S.; Costa, D.B. EGFR Exon 20 Insertion Mutations Display Sensitivity to Hsp90 Inhibition in Preclinical Models and Lung Adenocarcinomas. Clin. Cancer Res. 2018, 24, 6548-6555. [CrossRef] [PubMed]

84. Piotrowska, Z.; Yu, H.A.; Yang, J.C.-H.; Koczywas, M.; Smit, E.F.; Tan, D.S.-W.; Lee, V.H.-F.; Soo, R.A.; Wrangle, J.M.; Spira, A.I.; et al. Safety and activity of CLN-081 (TAS6417) in NSCLC with EGFR Exon 20 insertion mutations (Ins20). J. Clin. Oncol. 2021, 39, 9077. [CrossRef]

85. Li, S.; Schmitz, K.R.; Jeffrey, P.D.; Wiltzius, J.J.W.; Kussie, P.; Ferguson, K.M. Structural basis for inhibition of the epidermal growth factor receptor by cetuximab. Cancer Cell 2005, 7, 301-311. [CrossRef] [PubMed]

86. Hasegawa, H.; Yasuda, H.; Hamamoto, J.; Masuzawa, K.; Tani, T.; Nukaga, S.; Hirano, T.; Kobayashi, K.; Manabe, T.; Terai, H.; et al. Efficacy of afatinib or osimertinib plus cetuximab combination therapy for non-small-cell lung cancer with EGFR exon 20 insertion mutations. Lung Cancer 2018, 127, 146-152. [CrossRef] 
87. van Veggel, B.; de Langen, A.J.; Hashemi, S.M.S.; Monkhorst, K.; Heideman, D.A.M.; Thunnissen, E.; Smit, E.F. Afatinib and Cetuximab in Four Patients with EGFR Exon 20 Insertion-Positive Advanced NSCLC. J. Thorac. Oncol. 2018, 13, 1222-1226. [CrossRef] [PubMed]

88. van Veggel, B.; van der Wekken, A.J.; Paats, M.; Hashemi, S.M.; Hendriks, L.; Sikorska, K.; Broek, D.V.D.; Monkhorst, K.; Smit, E.F.; De Langen, J. Interim results of a phase II single arm trial combining afatinib with cetuximab in patients with EGFRex20ins positive NSCLC. J. Clin. Oncol. 2021, 39, 9112. [CrossRef]

89. Bagchi, A.; Haidar, J.N.; Eastman, S.W.; Vieth, M.; Topper, M.; Iacolina, M.D.; Walker, J.M.; Forest, A.; Shen, Y.; Novosiadly, R.D.; et al. Molecular Basis for Necitumumab Inhibition of EGFR Variants Associated with Acquired Cetuximab Resistance. Mol. Cancer Ther. 2018, 17, 521-531. [CrossRef]

90. Riess, J.W.; Groshen, S.G.; Reckamp, K.L.; Wakelee, H.A.; Oxnard, G.R.; Padda, S.K.; Koczywas, M.; Piotrowska, Z.; Sholl, L.M.; Paweletz, C.P.; et al. Osimertinib (Osi) plus necitumumab (Neci) in EGFR-mutant NSCLC: An ETCTN California cancer consortium phase I study. J. Clin. Oncol. 2019, 37, 9057. [CrossRef]

91. Shu, C.A.; Goto, K.; Cho, B.C.; Griesinger, F.; Yang, J.C.-H.; Felip, E.; Xie, J.; Chen, J.; Mahoney, J.; Thayu, M.; et al. CHRYSALIS-2: A phase $1 / 1 b$ study of lazertinib as monotherapy and in combination with amivantamab in patients with EGFR-mutant NSCLC. J. Clin. Oncol. 2021, 39, TPS9132. [CrossRef]

92. Pacini, L.; Jenks, A.D.; Vyse, S.; Wilding, C.P.; Arthur, A.; Huang, P.H. Tackling Drug Resistance in EGFR Exon 20 Insertion Mutant Lung Cancer. Pharm. Pers. Med. 2021, 14, 301-317. [CrossRef]

93. Elamin, Y.; Robichaux, J.; Carter, B.; Altan, M.; Gibbons, D.; Fossella, F.; Simon, G.; Lam, V.; Blumenschein, G.; Tsao, A.; et al. MA09.03 Identification of Mechanisms of Acquired Resistance to Poziotinib in EGFR Exon 20 Mutant Non-Small Cell Lung Cancer (NSCLC). J. Thorac. Oncol. 2019, 14, S282-S283. [CrossRef]

94. Zhou, W.; Ercan, D.; Chen, L.; Yun, C.-H.; Li, D.; Capelletti, M.; Cortot, A.B.; Chirieac, L.; Iacob, R.E.; Padera, R.; et al. Novel mutant-selective EGFR kinase inhibitors against EGFR T790M. Nature 2009, 462, 1070-1074. [CrossRef]

95. Ramalingam, S.S.; Cheng, Y.; Zhou, C.; Ohe, Y.; Imamura, F.; Cho, B.C.; Lin, M.C.; Majem, M.; Shah, R.; Rukazenkov, Y.; et al. Mechanisms of acquired resistance to first-line osimertinib: Preliminary data from the phase III FLAURA study. Ann. Oncol. 2018, 29, viii740. [CrossRef]

96. Yun, C.-H.; Mengwasser, K.E.; Toms, A.V.; Woo, M.S.; Greulich, H.; Wong, K.K.; Meyerson, M.; Eck, M.J. The T790M mutation in EGFR kinase causes drug resistance by increasing the affinity for ATP. Proc. Natl. Acad. Sci. USA 2008, 105, 2070-2075. [CrossRef] [PubMed]

97. Chouitar, J.; Vincent, S.; Brake, R.; Li, S. P2.13-32 TAK-788 is a Novel and Potent Tyrosine Kinase Inhibitor with Selective Activity Against EGFR/HER2. J. Thorac. Oncol. 2018, 13, S811. [CrossRef]

98. Qin, Q.; Li, X.; Liang, X.; Zeng, L.; Wang, J.; Sun, L.; Zhong, D. CDK4/6 inhibitor palbociclib overcomes acquired resistance to third-generation EGFR inhibitor osimertinib in non-small cell lung cancer (NSCLC). Thorac. Cancer 2020, 11, 2389-2397. [CrossRef] [PubMed]

99. Engelman, J.A.; Zejnullahu, K.; Mitsudomi, T.; Song, Y.; Hyland, C.; Park, J.O.; Lindeman, N.; Gale, C.-M.; Zhao, X.; Christensen, J.; et al. MET Amplification Leads to Gefitinib Resistance in Lung Cancer by Activating ERBB3 Signaling. Science 2007, 316, 1039-1043. [CrossRef]

100. Brown, N.A.; Plouffe, K.R.; Yilmaz, O.; Weindorf, S.C.; Betz, B.L.; Carey, T.E.; Seethala, R.R.; McHugh, J.B.; Tomlins, S.A.; Udager, A.M. TP53 mutations and CDKN2A mutations/deletions are highly recurrent molecular alterations in the ma-lignant progression of sinonasal papillomas. Mod. Pathol. 2020, 34, 1133-1142. [CrossRef] [PubMed]

101. Uchi, R.; Jiromaru, R.; Yasumatsu, R.; Yamamoto, H.; Hongo, T.; Manako, T.; Sato, K.; Hashimoto, K.; Wakasaki, T.; Matsuo, M.; et al. Genomic Sequencing of Cancer-related Genes in Sinonasal Squamous Cell Carcinoma and Coexisting Inverted Papilloma. Anticancer. Res. 2021, 41, 71-79. [CrossRef] [PubMed]

102. Riess, J.W.; Gandara, D.R.; Frampton, G.M.; Madison, R.; Peled, N.; Bufill, J.A.; Dy, G.K.; Ou, S.H.I.; Stephens, P.J.; McPherson, J.D.; et al. Diverse EGFR Exon 20 Insertions and Co-Occurring Molecular Alterations Identified by Comprehensive Ge-nomic Profiling of Non-Small Cell Lung Cancer. J. Thorac. Oncol. 2018, 13, 1560. [CrossRef]

103. Shien, K.; Toyooka, S.; Yamamoto, H.; Soh, J.; Jida, M.; Thu, K.L.; Maki, Y.; Ichihara, E.; Asano, H.; Tsukuda, K.; et al. Acquired Resistance to EGFR Inhibitors Is Associated with a Manifestation of Stem cell-like Properties in Cancer Cells. Cancer Res. 2015, 73, 3051-3061. [CrossRef] [PubMed]

104. Weng, C.H.; Chen, L.Y.; Lin, Y.C.; Shih, J.Y.; Lin, Y.C.; Tseng, R.Y.; Chiu, A.C.; Yeh, Y.H.; Liu, C.; Lin, Y.T.; et al. Epithelialmesenchymal transition (EMT) beyond EGFR mutations per se is a common mechanism for ac-quired resistance to EGFR TKI. Oncogene 2019, 38, 455-468. [CrossRef] [PubMed]

105. Hata, A.N.; Niederst, M.J.; Archibald, H.L.; Gomez-Caraballo, M.; Siddiqui, F.M.; Mulvey, H.E.; Maruvka, Y.E.; Ji, F.; Bhang, H.-E.C.; Radhakrishna, V.K.; et al. Tumor cells can follow distinct evolutionary paths to become resistant to epidermal growth factor receptor inhibition. Nat. Med. 2016, 22, 262-269. [CrossRef] [PubMed]

106. Ramirez, M.; Rajaram, S.; Steininger, R.J.; Osipchuk, D.; Roth, M.A.; Morinishi, L.S.; Evans, L.; Ji, W.; Hsu, C.-H.; Thurley, K.; et al. Diverse drug-resistance mechanisms can emerge from drug-tolerant cancer persister cells. Nat. Commun. 2016, 7, 10690. [CrossRef] [PubMed]

107. Sharma, S.V.; Lee, D.Y.; Li, B.; Quinlan, M.P.; Takahashi, F.; Maheswaran, S.; McDermott, U.; Azizian, N.; Zou, L.; Fischbach, M.A.; et al. A Chromatin-Mediated Reversible Drug-Tolerant State in Cancer Cell Subpopulations. Cell 2010, 141, 69-80. [CrossRef] 